\title{
Design and Optimization of Standalone Photovoltaic Power System for Ethiopian Rural School Electrification
}

\author{
Sintayehu Assefa Endaylalu \\ Mechanical Engineering Department, Debre Berhan University, Debre Berhan, Ethiopia
}

Email address:

sintayehuassefa@dbu.edu.et, sintaman2001@gmail.com

\section{To cite this article:}

Sintayehu Assefa Endaylalu. Design and Optimization of Standalone Photovoltaic Power System for Ethiopian Rural School Electrification. American Journal of Energy Engineering. Vol. 6, No. 2, 2018, pp. 15-20. doi: 10.11648/j.ajee.20180602.12

Received: July 6, 2018; Accepted: August 9, 2018; Published: September 6, 2018

\begin{abstract}
Power is one of the basic need of the Ethiopian society and organization for cooking, lighting and to run different office or other place electrical devices like TV, radio, computer, fans etc. In Ethiopia grid electrical power supply is still not supplied to rural communities or organization due to the geographical topography difficulty as well as the shortage of grid power and Ethiopia has enough potential of solar energy resource. This paper presents a renewable standalone photo voltaic power system to electrify the selected rural school which are far from grid power supply for ceiling fan, office phone, lighting, computer, printer, radio and TV consumption. Therefore, this study focused on the design and optimization of the power system components by using homer software. The solar resource of the for the school site is collected. The electrical energy demand of the selected school, number of PV modules, payback period and other corresponding components as well as the initial cost estimation of the power system components and optimization of the standalone power system is done by homer software. There are 42 solar photo voltaic modules needed for the estimation energy demand of school with the energy cost of the power generated $0.13 \$ / \mathrm{kwh}$ and cash inflow $3431.1 \$ /$ year for the payback period of 6.5 years.
\end{abstract}

Keywords: Standalone, Homer, Optimization, Payback Period

\section{Introduction}

Energy is the primary and most universal consumable by human beings and nature. Everything happens in the world is the expression of flow of energy in one of its forms i.e. thermal energy or heat energy, electrical energy, and chemical energy.
The source of each form of energy is different, since they are different type of energy. Generally, the source of energy is fossil fuel, nuclear power, solar, wind, tidal, hydro, geothermal, and bio-fuel. Electrical energy for different function can be generated using a variety of means.

Table 1. An over view of renewable in Ethiopia [2].

\begin{tabular}{|c|c|c|c|c|c|}
\hline \multirow{2}{*}{ No } & \multirow{2}{*}{ Energy resources } & \multicolumn{4}{|c|}{ Energy in $10^{3}$ Tcal per year } \\
\hline & & Potential & \% Share & Exploitable & $\%$ Share \\
\hline 1 & solar radiation & $1,953,550$ & 99.71 & 954 & 73.08 \\
\hline 2 & Wind & 4,779 & 0.24 & 239 & 8.94 \\
\hline 3 & Forest Biomass & 800 & 0.005 & 240 & 8.97 \\
\hline 4 & Hydro power & 552.1 & 0.03 & 138 & 5.16 \\
\hline 5 & Animal Waste & 111.28 & 0.01 & 33.73 & 1.26 \\
\hline 6 & Crop Residue & 81.36 & 0.0004 & 40.63 & 1.52 \\
\hline & Total & $1,959,901.93$ & 100.0 & $2,673.5$ & 100 \\
\hline
\end{tabular}

Ethiopia is located in the eastern part of Africa between $3^{\circ}$ to $15^{\circ}$ north and $33^{\circ}$ to $48^{\circ}$ east with a surface area of 1.1 million square kilometer. It has a topography of different mountains and valleys. Similarly, the country is largest in area. It is also the second most populous country in Sub Saharan Africa with an estimated population of about 88 million, which is mostly 
distributed in northern, central and southwestern highlands. There is a various energy resource potential in Ethiopia, which could reduce the present energy shortage prevailing in the country and increases the aim of rural electrification. The total amount of renewable energy that can be taken annually from primary solar, wind, forest biomass, hydropower, animal waste, crop residue as well as human waste is about $1,959,901.93 \times 10^{3}$ Tcal per year as it can be seen in table 1 . Among this, the share of solar radiation is about $73.08 \%$, while the share of biomass resources is about $12.8 \%$ [1].

Since Ethiopia is situating very close to the equator (between 30 and 150 degrees North) and share enough amount of solar energy potential which can be collected and put to use in the form of both thermal as well as electrical energy. Most researches indicate that for Ethiopia the yearly average daily solar radiation reaching the ground is around $5.26 \mathrm{kWh} / \mathrm{m}^{2}$ day [1].

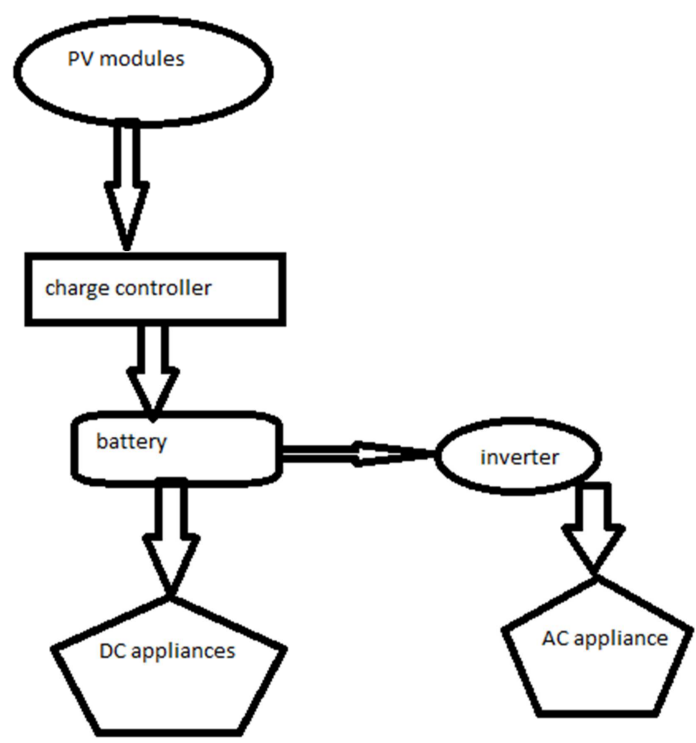

Figure 1. Main components off-grid PV components

Ankober is one of the woredas found in amhara region in Ethiopia which is located with latitude $9.5962^{\circ} \mathrm{N}$ and $39.7324^{\circ} \mathrm{E}$ and altitude $2896 \mathrm{~m}$ above sea- level. Mehal wenzi elementary school is one of the school found near to Gorebela towns around $8 \mathrm{~km}$. The woredas school is required power to any activities like radio, lighting and TV. Therefore, the main objective of this paper is to design and optimize the standalone photo voltaic power system for rural school electrification purpose.

Generally, PV off grid power system has photovoltaic modules array, charge controller, battery, inverter, different switches, wiring and breaks.

The steps to size the photovoltaic power system was

(a) Collecting solar resources data's

(b) Estimation of the power consumption of the school

(c) Sizing of the photovoltaic modules array

(d) Charge controllers

(e) Battery sizing

(f) Inverter sizing

(g) Estimation of the investment cost

(h) Home optimization and conclusion

\section{Solar Resource Data's}

To design the required PV power system, first it is important collecting meteorological solar data for the site under consideration Debre Berhan town. The amount of useful sun shine available for the panels on average during the lost month is taken to safe the system will work year round without shortage of power. By assuming the current project is done near to Debre Berhan city. All data's for calculation purpose is taken from this town. Table 2 below shown the solar resource taken for design of the PV power system.

Table 2. Mean monthly sunshine hour and solar radiation.

\begin{tabular}{lll}
\hline & Monthly sunshine hrs & Radiation $\mathbf{k W h} / \mathbf{m}^{\mathbf{2}} \mathbf{d a y}$ \\
\hline Jan. & 8.9 & 5.90 \\
Feb. & 10.5 & 5.74 \\
Mar. & 7.4 & 6.15 \\
Apri. & 7.0 & 6.38 \\
May. & 6.9 & 6.65 \\
Jun. & 5.4 & 6.35 \\
Jul. & 3.2 & 5.32 \\
Aug. & 4.2 & 5.88 \\
Sept. & 6.4 & 6.11 \\
Oct. & 6.6 & 6.29 \\
Nov. & 8.8 & 6.06 \\
Dec. & 9.9 & 5.53 \\
\hline
\end{tabular}

\section{Estimation of the Power Consumption of the School}

The preferred method of determining photovoltaic system loads is by calculating the power demand (kwh/day) for all load types in the school. This is done by considering the watt on the label of equipment's or multiplying the amperage and voltage of the equipment's, and then multiplying by the number of hours it give for the average in watt-hour.

Table 3. Estimated electrical power consumption of school.

\begin{tabular}{|c|c|c|c|c|}
\hline Load type & Number of units & Rated power (w) & Hours used/ day & wh/day \\
\hline Ceiling fans & 1 & 50 & 8.0 & 400 \\
\hline Office Telephone & 1 & 24 & 24 & 576 \\
\hline Outdoor lighting Compact fluorescent & 18 & $16 \times 18=288$ & 12 & 3456 \\
\hline In door lighting Compact fluorescent & 40 & $11 \times 40=440$ & 12 & 5280 \\
\hline Computer-desktop & 1 & 100 & 8.0 & 800 \\
\hline Computer printer & 1 & 100 & 2.0 & 200 \\
\hline Television $21 "$ & 1 & 250 & 8 & 1400 \\
\hline Total & & & & 12472 \\
\hline
\end{tabular}


For complex loads like school, it is sometimes difficult to anticipate every electrical load. TVs and other appliances sometimes draw small amounts of power even when they are turned off. For this reason, mostly recommend multiplying the estimated daily load by a "load correction factor" 1.5 [8]. The daily energy consumption of school with the above utilities (fudge factor) or load correction factor will be, daily energy usage $=1.5 \times 12.472=18.708 \mathrm{kWhr} /$ day and the yearly energy demand is calculated by multiplying the above daily energy usage by the number of days in the year those equipment's are used. Therefore, The annual energy and the total photovoltaic energy need is $6828.42 \mathrm{kWhr} /$ year.

\section{Power System Components Configuration}

Electrical power can generate by using different resources like wind, hydro, geothermal, solar and etc. As shown in figure 2 below the standalone photovoltaic power system is selected and have main components like PV modules, charge controller, batter, inverter and other electrical wiring as well as different accessories switches. Initially the PV modules produce DC power and it will store in battery for non - sun shine, but there is a charge controller to regulate the voltage and current. The school all appliance is selected AC, so there is an inverter after battery storage.

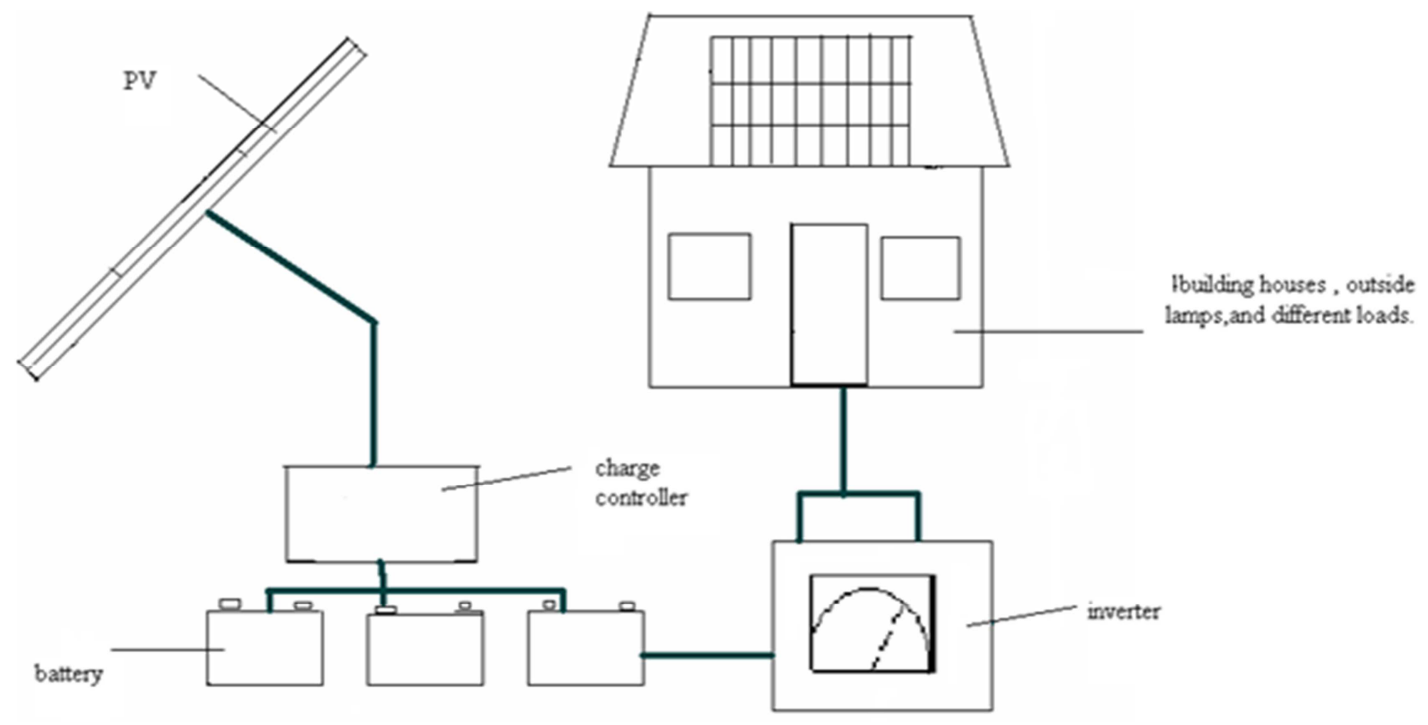

Figure 2. Standalone power system main components.

Generally, the off-grid photovoltaic power system design in two ways i.e. centralized and decentralized power stations. Centralized power station is designing by considering one power source station and distribute the generate power to demand organization or community, but decentralized power source station is designing by considering different or many power source for each organization or community.

\subsection{Sizing of Photo Voltaic Modules}

A PV powering load system will be used for every day, the number and size of array is determined by the daily energy need divided by the sun-shine per day.

$$
\text { PPv array }=\frac{E}{\eta_{\text {overall }} \times P S H}
$$

Where, $\mathrm{E}$ is the daily energy demand of the school = $18.708 \mathrm{kWhr} /$ day. PSH - the minimum peak sun hours per days. Therefore, the peak hour for the site exist in July month with $3.2 \mathrm{hr} /$ day.

There are many factors which contributes for power losses in a system. Therefore, calculating or estimating the loss is need before sizing the panel.
The Inverter loss 6\% - 10\%, Wire losses 3\% -7\%, Build up losses 5 to $15 \%$, and considering battery efficiency is $85 \%$, that means it accounts $15 \%$ loss of power during charging and discharging [4]. Therefore, considering the above component loss efficiency and the overall efficiency will become the product of the above. Therefore,

$$
\begin{aligned}
\eta_{\text {overall }}=\left(\eta_{\text {inverter }} \times \eta_{\text {Wiring }} \times \eta_{\text {build up }}\right. & \\
& \left.\times \eta_{\text {panal tilt }} \times \eta_{\text {battery }}\right) \\
& =0.92 \times 0.95 \times 0.90 \times 0.89 \times 0.85 \\
& =0.60=60 \% .
\end{aligned}
$$

$$
\operatorname{PPv} \text { array }=\frac{E}{\begin{array}{c}
\eta_{\text {overall }} \times P S H \\
=9.85 \mathrm{~kW}
\end{array}}=\frac{18.708 \mathrm{kWhr} / \text { day }}{0.60 \times 3.2 \mathrm{hr} / \text { day }}
$$

Therefore, locally 240w PV panel with short circuit current (Isc) $8 \mathrm{Am}$ is available and 42 number of solar panel is selected. Since the array nominal voltage required is 24 volts. Then, the number of modules connected in series is 2 modules in series. Therefore, 21 modules are connected in 
parallel.

\subsection{Charge Controller}

The charge controller regulates the voltage and current coming from PV panel and going to battery similarly prevents battery over charging and prolongs the battery life. During the size of solar charge controller is to take the short circuit current (Isc) of the PV module array and multiply by 1.3 factor. Solar charge controller size $=8 \mathrm{Am} \times 1.3 \times 21$ modu $=218.4 \mathrm{~A}$. Therefore, the solar charge controller should rate $218.4 \mathrm{~A}$ at 24 volt. For this purpose $400 \mathrm{~W}$ rating selected.

\subsection{Battery Storage}

Batteries are main components in standalone power system. It is used for storage of DC power supply from PV panel for night and dark season usage. The storage capacity of the needed battery for this purpose is selected above 1873.8Ah.

\subsection{Inverter}

The inverter is used to convert DC stored power in battery to AC power for school equipment's loads. Mostly for safety operation of the inverter should size $25-30 \%$ larger than the total watts of loads. Since the power consumption load is around $18.708 \mathrm{kWh} /$ day or 779.5 watts, the inverter selected for this purpose is more than this watts.

\section{Material Cost}

The cost of the power system includes main components and it's installation. These include the prices of PV modules, the charge controller, the batteries, inverter and other all auxiliaries components. The estimated investment cost is summarized in the table 4 below.

Table 4. Estimated cost.

\begin{tabular}{llll}
\hline Items & Unit price (\$) & Amount & Cost (\$) \\
\hline PV modules & 270 & 42 & 11,340 \\
Charge controller & 39 & 25 & 975 \\
Battery & 500 & 16 & 8000 \\
Inverter & 950 & 1 & 950 \\
Switches & - & - & 300.00 \\
Wires, breakers, fuses & - & - & 400.00 \\
and other instruments & & - & 200.00 \\
Mounting Brackets & - & & 22,165 \\
Total & & & \\
\hline
\end{tabular}

\section{Energy Cost and Payback Period}

The energy cost of Ethiopia is cheap when it compared from other country or energy cost generated from renewable energy sources like PV, but it is the only solution to electrify remote areas and difficult geographical locations which far from grid power. The lifespan of PV power system averagely around twenty five years. Using a simple net present value calculation method the dynamic specific costs is calculated

$$
\begin{aligned}
& \text { Specific energy cost }\left(\frac{\$}{\mathrm{kWh}}\right)= \\
& \frac{\text { net present value of investment cost }(\$)}{\text { net present value of prodcution }(\mathrm{kWh})}
\end{aligned}
$$

Using equation (2) the specific energy cost is $0.13 \$ / \mathrm{kWh}$. This is somewhat cost when it is compared to Ethiopia electric energy cost but currently, it is best alternatives for remote areas.

The payback period of the power system determined, first by determining the cash inflows from the investment system with profits

$$
\text { Cash inflows }=\frac{\text { investment } \operatorname{cost}(\$)}{\frac{(1+\mathrm{i})^{\mathrm{n}}-1}{\left[\mathrm{i}(1+\mathrm{i})^{\mathrm{n}}\right]}}
$$

Where, $\mathrm{i}$ is the interest rate, currently in Ethiopia bank interest is around $15 \%$ and $n$ is the average service year of PV power system.

Similarly, using equation (3) the cash inflows is $3431.12 \$ /$ year.

Therefore, the payback period of the PV power system determine by

$$
\text { Payback period }=\frac{\text { investment cost }}{\text { cash inflows }}
$$

Therefore, the payback period gives 6.5 years. This implies the power system will return its investment cost.

\section{Optimization of the Power System}

Homer software simulates an optimal configuration of PV power system. The system consists of PV modules, batteries, and inverter. The following figure 2 shows the proposed system as implemented in homer simulation software tool.

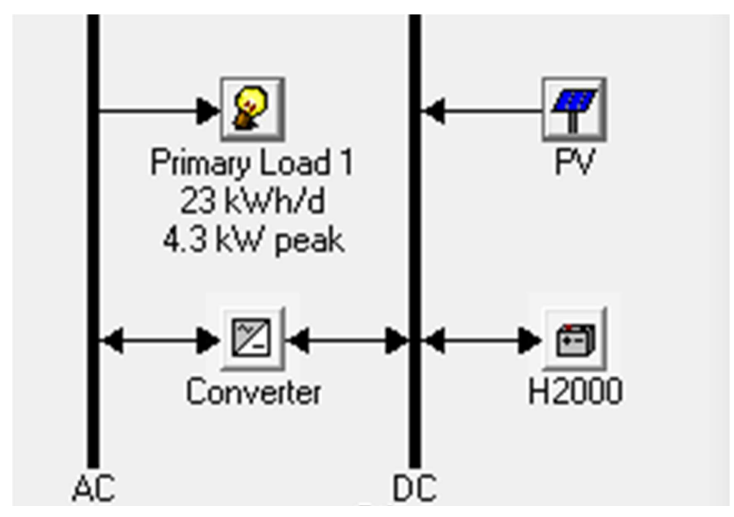

Figure 3. Standalone PV system in Homer.

The PV system generates average power also simulated as well as optimized as shown in the figure4 below. The PV array initially architect systematically or theoretically for $9.85 \mathrm{kWh}$, but the Homer simulation result given an optimized average PV array electric production annually $17506 \mathrm{kWh} /$ year to serve a power consumption of $\mathrm{AC}$ primary loads $6159 \mathrm{kWh} /$ year. 

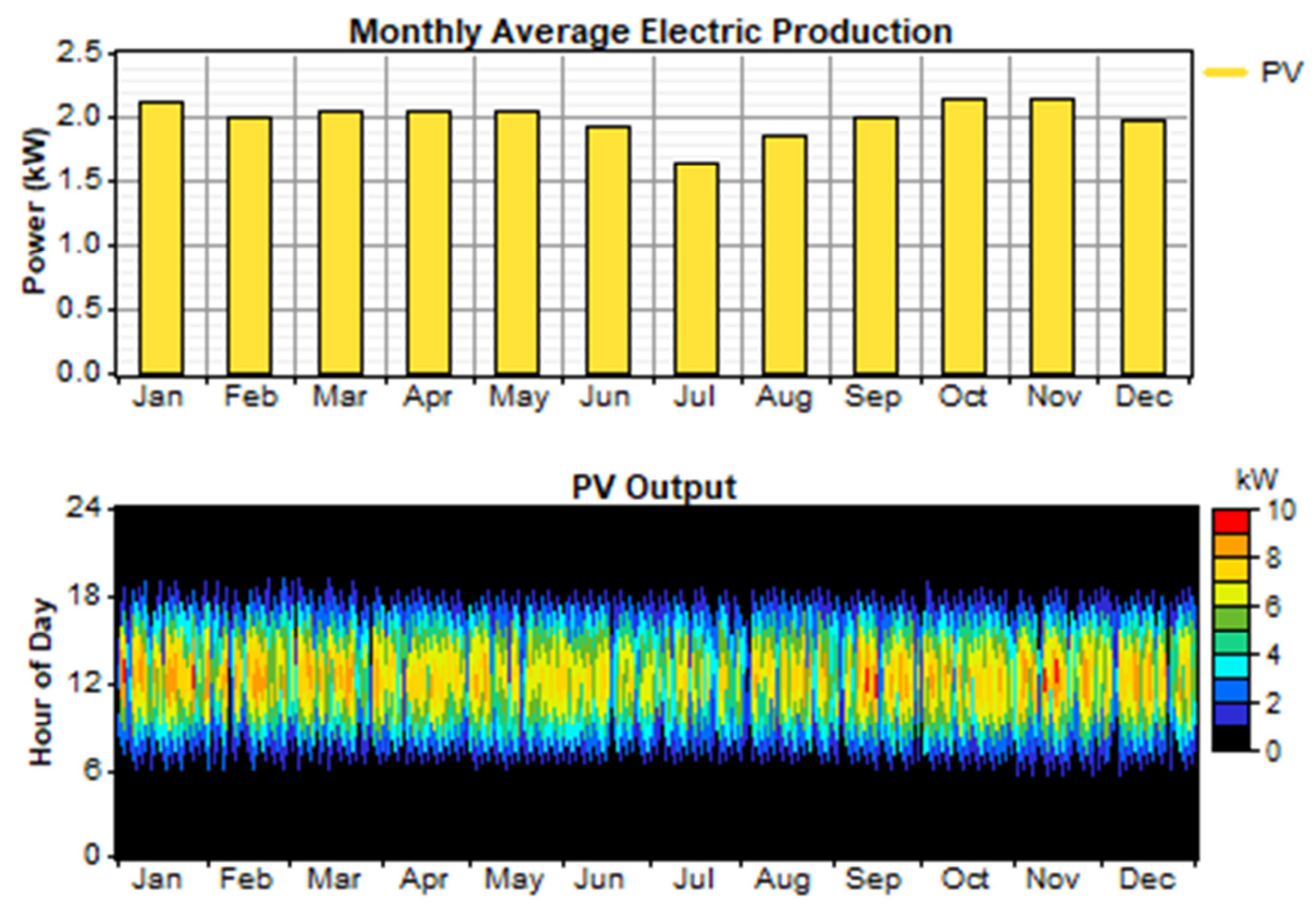

Figure 4. Monthly PV power output.

Figure 4 indicates the electric power generation based on the daily energy consumption estimation of school for each appliance running from PV system comparatively minimum in July and maximum in October, January, and November. The simulation result indicates to turn down all appliances at the same time, there is a need of additional power source to hybrid like electric generator and a periodical need of shift usage of each electrical equipment's. The red color shows the maximum power and the blue black color is the lowest power.

\subsection{Optimization Results}

The following figure5 shows the optimum result generates from solar radiation, load of school, economics and constraints. The configuration is a standalone PV system that supply the electrical energy with lowest cost.

\begin{tabular}{|c|c|c|c|c|c|c|c|c|c|c|}
\hline $9 \%$ & $\begin{array}{l}\text { PV } \\
(\mathrm{kW})\end{array}$ & $\mathrm{H} 2000$ & $\begin{array}{l}\text { Conv. } \\
(\mathrm{kW})\end{array}$ & $\begin{array}{l}\text { Disp. } \\
\text { Strgy }\end{array}$ & $\begin{array}{l}\text { Efficiency } \\
\text { Measures }\end{array}$ & $\begin{array}{l}\text { Initial } \\
\text { Capital }\end{array}$ & $\begin{array}{l}\text { Operating } \\
\text { Cost (\$/yr) }\end{array}$ & $\begin{array}{l}\text { Total } \\
\text { NPC }\end{array}$ & $\begin{array}{c}\mathrm{COE} \\
\text { (\$/kWh) }\end{array}$ & $\begin{array}{l}\text { Ren. } \\
\text { Frac. }\end{array}$ \\
\hline $9 \square$ & 9.85 & 16 & 16 & CC & No & $\$ 11.768$ & 6 & $\$ 11.846$ & 0.212 & 1.00 \\
\hline
\end{tabular}

Figure 5. The optimization result.

\subsection{Cost Results}

The cost result from homer software is as follows without considering the cost of charge controller and other all accessories. Based on the homer software optimization the initial cost is become around 12701 \$ without considering the cost of the charge controller and different wiring accessories.

\begin{tabular}{|l|r|r|r|r|r|r|r|}
\multicolumn{1}{|c|}{ Component } & Capital (\$) & Replacement (\$) & O\&M (\$) & Fuel (\$) & Salvage (\$) & Total (\$) \\
\hline PV & 11,340 & 0 & 0 & 0 & 0 & 11,340 \\
\hline Hoppecke 16 OPz 200 & 333 & 104 & 0 & 0 & -58 & 379 \\
\hline Converter & 950 & 40 & 0 & 0 & -7 & 982 \\
\hline System & 12,623 & 144 & 0 & 0 & -66 & 12,701 \\
\hline
\end{tabular}

Figure 6. Cost result. 


\section{Conclusion}

This research is focused on the design of photo voltaic system for rural school electrification for the purpose of lighting and basic necessary electrical load equipment's power supplying. The energy demand of school is $6828.42 \mathrm{kWhr} /$ year. Around 42 photo voltaic modules of 240watt of each,16hoppecke12PZS1500, with charge controller and total investment costs of $22,165 \$$ is required. The system is also optimized with homer software for various daily energy demand and the result indicated the PV array produce electricity annually $17506 \mathrm{kWh} /$ year to serve a power consumption of AC primary loads $6159 \mathrm{kWh} /$ year.

\section{References}

[1] Aklilu Dalelo (phd). rural electrification in ethiopia: opportunities and bottlenecks. addis ababa university, college of education, department of geography and environmental education.

[2] Desta Goytom, feasibility study on pv-diesel hybrid power system for rural electrification: guaguata village, bahiirdar university, june, 2010.

[3] Amala. Hassan (2010), standalone photovoltaic system for an emergency health clinic, international conference on renewable energies and power quality (ICREPQ'10), 23rd to 25th march 2010, Granada, Spain.

[4] Assad Abu-Jasser (2010), a stand-alone photovoltaic system, case study: a residence in Gaza, open access http://www.trisanita.org, Received: 19th November 2009; Revised: 25th January 2010; Accepted: 3rd February 2010.

[5] Stand-Alone Photovoltaic Systems: Handbook of Recommended Design Practices, Sandia National Laboratory, Document No. SAND87-7023, available from National Technical Information Service, U.S. Department of Commerce, 5285 Port Royal Road, Springfield, VA 22161, 1991 (revised).

[6] Sadique, S. E., Ali, A. and Wang, D. (2012) Virtual Optimization of a Wireless, Solar PV/Wind Hybrid System. controller for Street-Lighting Applications based on Environmental Conditions in Greater Toronto Area, Proceedings of the 2012 International Conference on Industrial Engineering and Operations Management Istanbul, Turkey, July 3-6, 2012.
[7] S. N. SINGH and A. K. SINGH (2010), optimal design of a cost effective solar home power system - an alternative solution to $\mathrm{dg}$ for grid deprived rural India, International Journal of Research and Reviews in Applied Sciences, Volume 2, Issue 1 (January 2010), Jamshedpur, India.

[8] Chel, A., Tiwari, G. N., \& Chandra, A. (2009). Sizing and cost estimation methodology for stand-alone residential PV power system. International journal of agile Systems and management, 4(1-2), 21-40.

[9] Hammad Abo-zied Mohammed, “ design and implementation of a photo voltaic system used for street lights", $20162^{\text {nd }}$ international conference on control science and systems engineering, 2016.

[10] Kessler, W. (2017). Comparing energy payback and simple payback period for solar photovoltaic systems. In E3S Web of Conferences (Vol. 22, p. 00080). EDP Sciences.

[11] Palanov, N. (2014). Life-cycle assessment of Photovaltaic systems: analysis of environmental impact from the production of PV system including solar panels produced by Gaia Solar. TVBH-5074.

[12] Uwibambe, J. (2017). Design of Photovoltaic System for Rural Electrification in Rwanda (Master's thesis, Universitetet i Agder; University of Agder).

[13] Maleki, A., Rosen, M. A., \& Pourfayaz, F. (2017). Optimal operation of a grid-connected hybrid renewable energy system for residential applications. Sustainability, 9(8), 1314.

[14] Badoud, A. E., \& Khemliche, M. (2013). Modeling, Design and Simulation of Stand-Alone Photovoltaic Power Systems with Battery Storage. Leonardo Journal of Sciences, 22, 123142 .

[15] Trejos, A., Gonzalez, D., \& Ramos-Paja, C. A. (2012). Modeling of step-up grid-connected photovoltaic systems for control purposes. Energies, 5(6), 1900-1926.

[16] Petrone, G., \& Ramos-Paja, C. A. (2011). Modeling of photovoltaic fields in mismatched conditions for energy yield evaluations. Electric power systems research, 81(4), 10031013.

[17] Xiaodong, Y., Yan, Z., \& Weiping, Z. (2015). Real-Time Simulation and Research on Photovoltaic Power System based on RT-LAB. The Open Fuels \& Energy Science Journal, 8(1).

[18] Romero-Cadaval, E., Spagnuolo, G., Franquelo, L. G., Ramos-Paja, C. A., Suntio, T., \& Xiao, W. M. (2013). Gridconnected photovoltaic generation plants: Components and operation. IEEE Industrial Electronics Magazine, 7(3), 6-20. 